\title{
Expression of epiregulin and amphiregulin in the rat ovary
}

\section{T Sekiguchi, T Mizutani, K Yamada, T Kajitani, T Yazawa, M Yoshino and K Miyamoto}

\author{
Department of Biochemistry, Faculty of Medical Sciences, University of Fukui, 23 Shimoaizuki, Matsuoka, Fukui 910-1193, Japan, CREST, JST \\ (Japan Science and Technology, Kavaguchi, Saitama, 332-0012, Japan) \\ (Requests for offprints should be addressed to K Miyamoto; Email: kmiyamot@ fmsrsa.fukui-med.ac.jp)
}

\begin{abstract}
We have previously reported that the epidermal growth factor (EGF) family growth factor, epiregulin, is expressed in rat ovarian granulosa cells by induction with pregnant mare serum gonadotropin (PMSG). In this study, we report that amphiregulin, another member of the EGF family, was also induced in the rat ovary by gonadotropin treatment. Northern blot analysis revealed that PMSG treatment induced the expression of both epiregulin and amphiregulin mRNA after $24 \mathrm{~h}$, but the expression then decreased $48 \mathrm{~h}$ after treatment. Further treatment with human chorionic gonadotropin (hCG) rapidly induced the expression of both epiregulin and amphiregulin genes and maximal levels were reached $4 \mathrm{~h}$ after $\mathrm{hCG}$ treatment. A marginal increase in amphiregulin mRNA levels was also observed $6 \mathrm{~h}$ after PMSG treatment. In situ hybridization revealed that epiregulin and amphiregulin mRNAs were localized in the granulosa cells of large antral follicles. These spatio-temporal expression patterns were similar to those of cyclo-oxygenase-2 (COX-2) and progesterone receptor (PR). In adult cycling rats, epiregulin and amphiregulin were strongly induced at 1800 and $2000 \mathrm{~h}$ on proestrus coinciding with the preovulatory LH surge. An in situ hybridization study also showed that epiregulin and amphiregulin mRNAs were detectable in the granulosa cells of preovulatory ovarian follicles at $2000 \mathrm{~h}$ on proestrus, where transcripts of COX-2 and PR were co-localized with those of epiregulin and amphiregulin. These observations suggested that the EGF family members, epiregulin and amphiregulin, may play a role in the ovulatory process of cycling rats as well as in the induction of ovulation in immature rats.
\end{abstract}

Journal of Molecular Endocrinology (2004) 33, 281-291

\section{Introduction}

While pituitary luteinizing hormone (LH) and follicle-stimulating hormone (FSH) play central roles in the regulation of normal reproductive development and functions, a large number of growth factors serve as paracrine and autocrine factors in a gonadotropin-dependent or -independent fashion (Leung \& Steele 1992, Richards 1994). The epidermal growth factor (EGF) family growth factors, EGF and transforming growth factor- $\alpha(\mathrm{TGF}-\alpha)$, are also thought to be involved in this process. Both act as mitogens (Roy \& Greenwald 1991, Liang et al. 1994) and modulators of FSH-stimulated steroid secretion (Hsueh et al. 1981) in ovarian granulosa cells. Furthermore, EGF induces cumulus expansion and oocyte maturation that usually occurs after the preovulatory LH surge (Downs 1989, Das et al. 1992, Prochazka et al. 2000).

We previously isolated hundreds of clones of FSH-inducible genes from rat ovarian granulosa cells by subtraction cloning (Kameda et al. 1999), and an EGF growth factor family member, epiregulin, was included in these clones (Sekiguchi et al. 2002).

Epiregulin has been identified as a growthinhibitory factor from the conditioned medium of a fibroblast tumor cell line, NIH-3T3/clone T7 (Toyoda et al. 1995a). The gene expression profiles of epiregulin in human (Toyoda et al. 1997) and mouse (Toyoda et al. 1995b) tissue have been reported. Northern blot analyses have shown that the expression of human epiregulin occurs mainly 
A

a

36B4

B

epiregulin

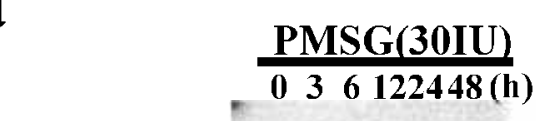

b

$$
\frac{\text { PMSG }}{02448} \frac{\text { hCG (30IU) }}{12481224(\mathrm{~h})}
$$

$428 S$ $-18 \mathrm{~S}$

epiregulin

36B4

BF

a

control

b

PMSG

24h

c

hCG 4h
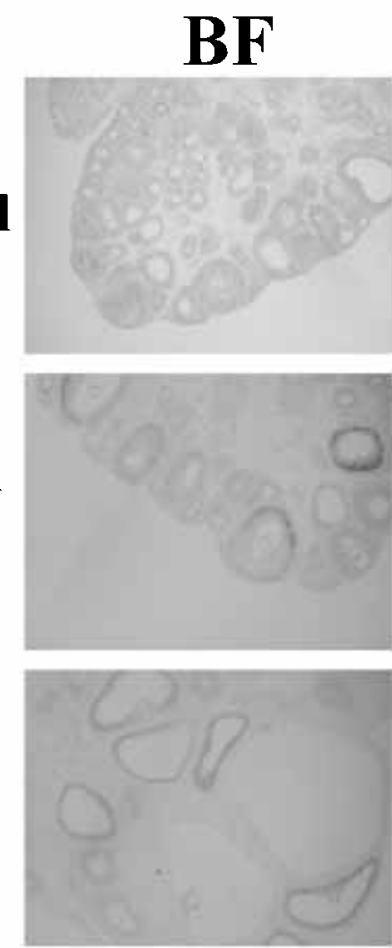

d

hCG $4 h$ sense
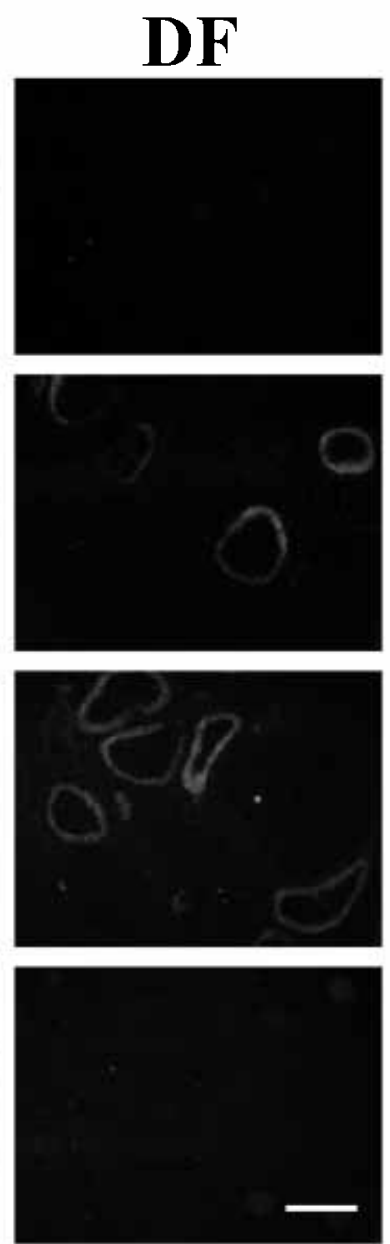
in peripheral blood macrophages and the placenta. In contrast, the mouse epiregulin gene has been detected in the uterus of an adult mouse and a 7-day-old mouse embryo by Northern blot analysis. In addition, several studies have reported on the epiregulin mRNA expression in bovine (Robert et al. 2001) and rat (Espey \& Richards 2002, Burns et al. 2003) ovarian granulosa cells.

In addition, we report here for the first time that another EGF family growth factor, amphiregulin, is also induced in the rat ovary by gonadotropin treatment. Amphiregulin was originally isolated from the conditioned medium of a human breast carcinoma cell line MCF-7 (Shoyab et al. 1988). In the rat, amphiregulin was purified from the growth-conditioned medium of the JS1 Schwann cell line (Kimura et al. 1990), and therefore is referred to as Schwannoma-derived growth factor. High levels of rat amphiregulin transcripts have been detected in the lungs of newborn animals, and lower levels were found in fetal and adult brains, as well as in sciatic nerves, as evidenced by Northern blot analysis. Several studies have reported that amphiregulin is associated with lung branching morphogenesis in the mouse (Schuger et al. 1996) and epithelial branching in the embryonic mouse kidney (Lee et al. 1999).

However, the roles of rat epiregulin and amphiregulin in the ovary are completely unknown. In this study, we report on an examination of the hormonal regulation and precise distribution of epiregulin and amphiregulin in the rat ovary, using cycling adult rats as well as immature rats in which superovulation was induced by treatment with gonadotropins. We have demonstrated here that the ovarian expression of rat epiregulin and amphiregulin coincides with those of cyclo-oxygenase-2 (COX-2) and progesterone receptor (PR), both of which are known to play integral roles in ovulation. These observations suggest that rat epiregulin and amphiregulin are induced by the preovulatory LH surge, and may be associated with ovulatory events.

\section{Materials and methods}

\section{Materials}

Pregnant mare serum gonadotropin (PMSG) was obtained from Teikokuzouki, Inc. (Tokyo, Japan). hCG was obtained from Sankyo Co. Ltd (Tokyo, Japan). T7 and SP6 RNA polymerase were obtained from Roche Molecular Biochemicals (Mannheim, Germany). The ToRizol reagent, Superscript II reverse transcriptase, and cloning vector pSPORT1 were purchased from Invitrogen (Carlsbad, CA, USA). $\alpha^{-32} \mathrm{P}$ dCTP (111 TBq/ $\mathrm{mmol})$ and ${ }^{35} \mathrm{~S}-\mathrm{CTP} \quad(46 \cdot 2 \mathrm{TBq} / \mathrm{mmol})$ were obtained from NEN Life Science Products (Wilmington, DE, USA). The pGEM-T Easy vector was purchased from Promega (Madison, WI, USA). The EX Taq DNA polymerase and $B c a$ BEST Labeling Kit were purchased from TaKaRa Shuzo (Kyoto, Japan).

\section{Animals and hormone treatments}

Immature, kwl: Wistar female rats (21 days old) were injected with 30 IU PMSG, and $48 \mathrm{~h}$ later with 30 IU hCG. Rats were killed at various time-points, and the ovaries were removed for Northern blot analysis or in situ hybridization analysis. Adult Iar: Wistar-Imamichi female rats (body weight 260-290 g) were housed in a photoperiod of $12 \mathrm{~h}$ light and $12 \mathrm{~h}$ darkness, with the lights on at $0800 \mathrm{~h}$. Estrous cycle stages were determined by a daily examination of vaginal cytology, and only those animals demonstrating at least two consecutive 4-day cycles were used in the experiments. Rats were killed and the ovaries were removed at $1400 \mathrm{~h}$ on each day of the cycle, and at 1600, 1800, 2000, 2200, and $2400 \mathrm{~h}$ on proestrus. Ovaries were rapidly frozen on dry ice for RNA isolation or fixed for in situ hybridization. At all times, the animals were treated according to NIH guidelines.

Figure 1 Expression pattern of rat epiregulin in the ovary. (A) Northern blot analysis of rat epiregulin mRNA in the ovary. Total RNA was isolated from ovaries removed at the indicated times. Rats were treated with (a) PMSG and (b) PMSG followed by hCG. Total RNA $(10 \mu \mathrm{g})$ from each run was loaded onto the lanes. After electrophoresis, the RNA was transferred to nylon membranes, which were hybridized with ${ }^{32} \mathrm{P}$-labeled cDNAs of epiregulin or 36B4. (B) In situ hybridization of epiregulin in immature rat ovaries. Ovaries from 21-day-old rats were dissected, sectioned, and hybridized with ${ }^{35}$ S-labeled antisense $(a, b$, and $c$ ) or sense (d) epiregulin probes. Rats were treated as follows: (a) no treatment, (b) PMSG for $24 \mathrm{~h}$, and (c and d) hCG for $4 \mathrm{~h}$ after $48 \mathrm{~h}$ of PMSG treatment. Left panels are bright-field exposures (BF); right panels are dark-field exposures (DF). A scale bar of $500 \mu \mathrm{m}$ is included. 


\section{A}

a

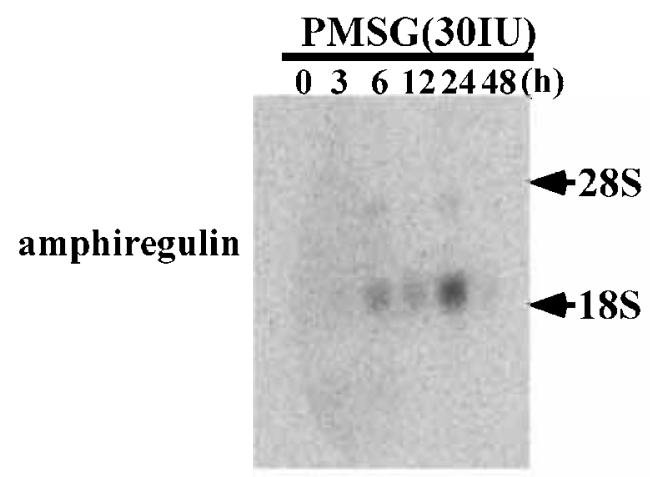

36B4

b

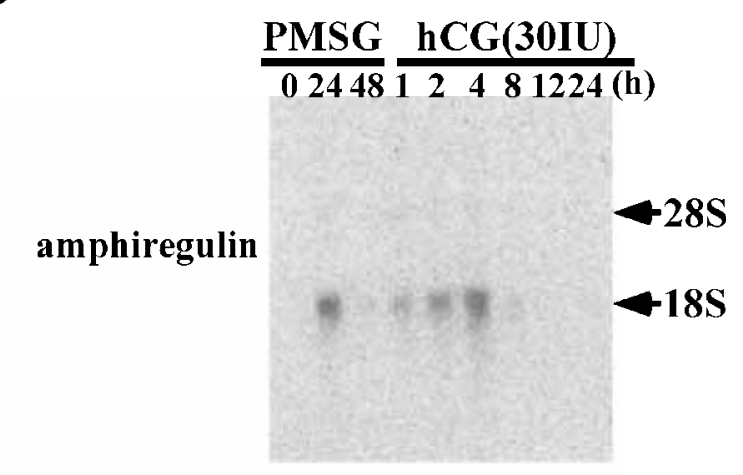

36B4

B

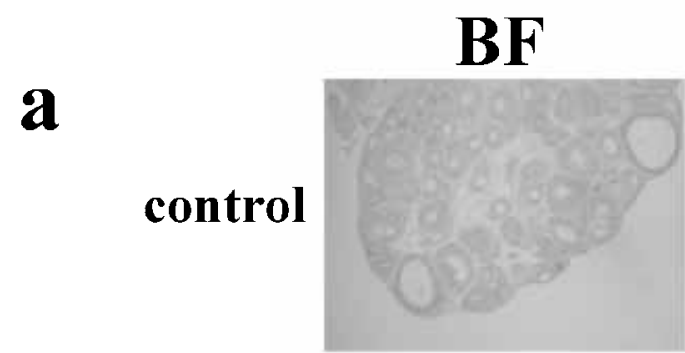

b

PMSG

24h

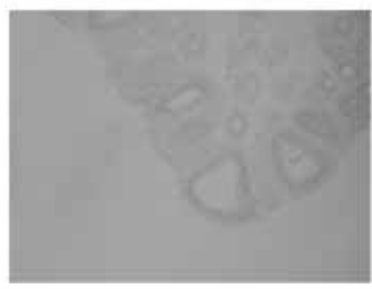

c
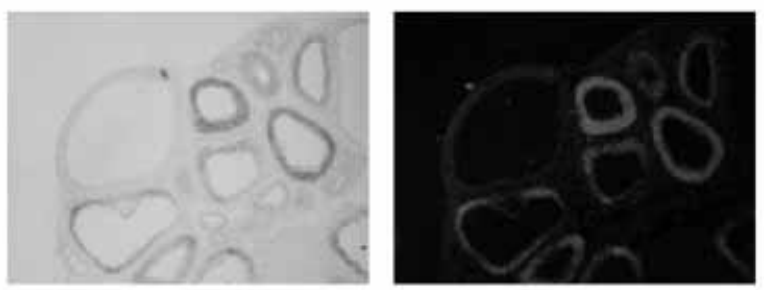

d

hCG 4h

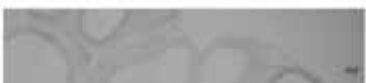

sense

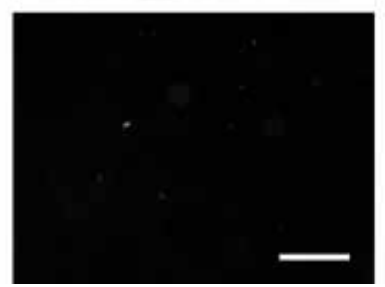




\section{Northern blot analysis and RT-PCR}

Total RNA was isolated by the acid guanidium thiocyanate extraction method (Chomczynski \& Sacchi 1987). For the Northern blot analysis, $10 \mu \mathrm{g}$ total RNA from each sample was separated by electrophoresis on denaturing agarose gels and subsequently transferred to a nylon membrane (Biodyne; ICN, Glen Gove, NY, USA). Rat epiregulin (MN-021689) cDNA fragment corresponding to bases $1-510$ and rat amphiregulin (NM-017123) cDNA fragment corresponding to bases 313-820 were radiolabeled by the random primer labeling method and used as a probe for RNA blot hybridization. Auto-radiographic bands were quantified by means of a fluoro-image analyzer (BAS2000; Fuji Co. Ltd, Kanagawa, Japan). The blots were striped and rehybridized with a randomly radiolabeled probe for a $954 \mathrm{bp}$ fragment of the pGEM-T Easy-36B4 encoding acidic ribosomal phosphoprotein $\mathrm{P} 0$ (36B4) (Yamada et al. 2003) to normalize for the equivalent loading of RNA. For RT-PCR, $1 \mu \mathrm{g}$ total RNA was reversetranscribed and a portion $(1 / 20)$ of the reaction mixture was subjected to the PCR reaction. Primers for rat epiregulin were 5'-CGCTTTG CGAGCTGCACGGA-3' (5'-primer: nucleotide (nt) 128/147) and 5'-GCGATTTGTGTACGAT CTGC-3' (3'-primer: nt 517/536) respectively. Primers for rat amphiregulin were 5'-CGCTG CTGGTCTTAGGCTCA-3' (5'-primer: nt 216/ 235) and 5'-GAA ACTTGGCGGGACACGGA-3' (3'-primer: nt 580/599) respectively. Primers for rat COX-2 were 5'-AGGAGAGACGATCAAG ATAGT-3' (5'-primer: nt 1093/1113) and 5'-ATA CAGTTCGATGGCATCGA-3' (3'-primer: nt $1575 / 1594)$ respectively. Primers for rat PR were 5'-CATGTCAGTGGACAGATGCT-3' (5'primer: nt 2278/2297) and 5'-ACTTCAGAC ATCATTTCGGG-3' (3'-primer: nt 2686/2705) respectively (Knauthe et al. 1996). Primers for rat
36B4 were 5'-GAACAACGCCGCTCTGGAGA-3' (5'-primer: nt 283/302) and 5'-GGCGTGCTCTG TGATGTCCA-3' (3'-primer: nt 684/703) respectively. The reaction conditions were 30 cycles for amphiregulin, and 25 cycles for epiregulin, COX2, PR, and 36B4 respectively, by denaturing at $94{ }^{\circ} \mathrm{C}$ for $20 \mathrm{~s}$, annealing for $30 \mathrm{~s}$ and extending at $72{ }^{\circ} \mathrm{C}$ for 1 min using the EX Taq DNA polymerase. Ten microliters of the PCR products were electrophoresed on a $1.5 \%$ agarose gel and subsequently visualized by ethidium bromide staining.

\section{In situ hybridization}

In situ hybridization was performed as described (Sekiguchi et al. 2002) with minor modifications using paraffin-embedded tissues instead of frozen tissues. Rat ovaries were fixed in freshly prepared $4 \%$ paraformaldehyde (PFA) at $4{ }^{\circ} \mathrm{C}$ for $12 \mathrm{~h}$, dehydrated with ethanol, cleared in xylene, and embedded in paraffin. Sections ( $5 \mu \mathrm{m}$ thick) were mounted on (3-aminopropyl) triethoxysilane-coated glass slides for in situ hybridization. The sections were deparaffinized, rehydrated, fixed in $4 \%$ PFA, treated with proteinase-K, post-fixed in $4 \%$ PFA, and acetylated before hybridization. Rat epiregulin cDNA fragment corresponding to bases $1-510$ and rat amphiregulin cDNA fragment corresponding to bases 313-820 were subcloned into the pSPORT1 vector and pGEM-T Easy vector respectively. Antisense or sense ${ }^{35} \mathrm{~S}-\mathrm{CTP}$-labeled RNA probes were synthesized using T7 or SP6 RNA polymerase. Hybridization with the ${ }^{35} \mathrm{~S}$-labeled cRNA probes was performed at $60{ }^{\circ} \mathrm{C}$ for $6 \mathrm{~h}$, and the sections were then washed under conditions of high stringency and autoradiographed using an NTB2 emulsion (Eastman Kodak Co., Rochester, NY, USA). After developing, all slides were counterstained with hematoxylin, dehydrated, and mounted.

Figure 2 Expression pattern of rat amphiregulin in the ovary. (A) Northern blot analysis of rat amphiregulin mRNA in the ovary. Total RNA was isolated from ovaries removed at the indicated times. Rats were treated with (a) PMSG or (b) PMSG followed by hCG. Total RNA $(10 \mu \mathrm{g})$ was loaded onto the lanes. After electrophoresis, RNA was transferred to nylon membranes, which were hybridized with ${ }^{32} \mathrm{P}$-labeled cDNAs of amphiregulin or 36B4. (B) In situ hybridization analysis of rat amphiregulin in an ovarian section. Localization of amphiregulin mRNA was examined by a ${ }^{35}$ S-labeled antisense (a, b, and c) or sense (d) amphiregulin probe. Ovaries were taken from 21-day-old immature rats treated as follows: (a) no treatment, (b) PMSG for $24 \mathrm{~h}$, and (c and d) hCG for $4 \mathrm{~h}$ after $48 \mathrm{~h}$ of PMSG treatment. Left panels are bright-field exposures (BF); right panels are dark-field exposures (DF). A scale bar of $500 \mu \mathrm{m}$ is included. 
A

$\frac{\text { PMSG }}{0244812481224(h)}$

epiregulin

amphiregulin

COX2

PR

36B4

B

PMSG48h+hCG4h

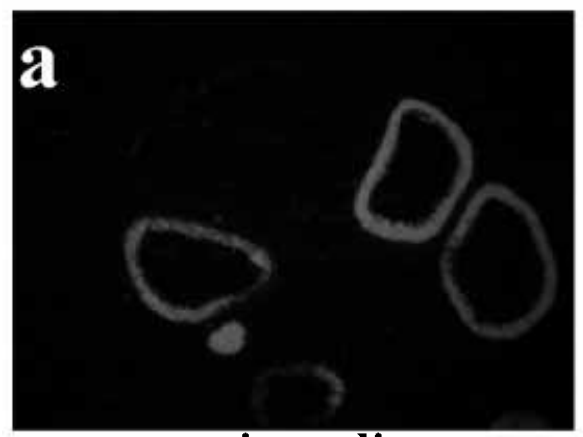

epiregulin

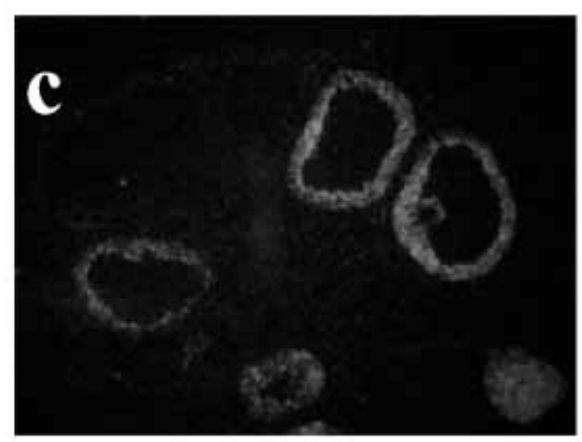

COX2

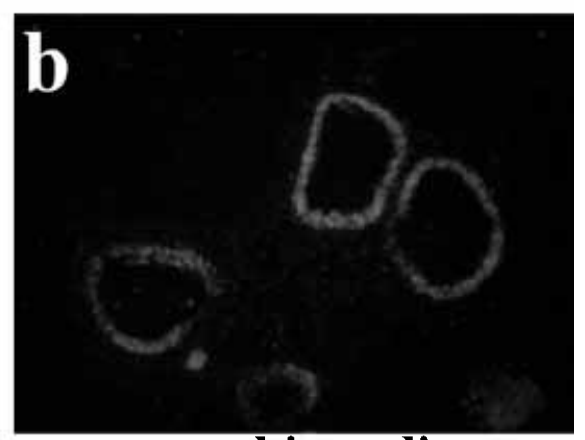

amphiregulin

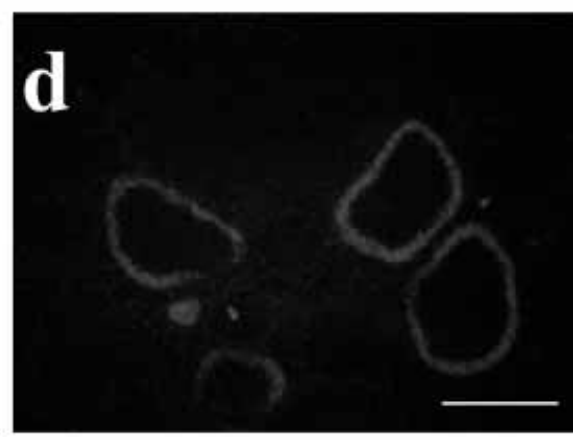

PR 


\section{Results}

We have previously shown that the expression of the epiregulin gene is strongly induced in rat ovarian granulosa cells by PMSG in vivo. In this study, we examined the hormonal regulation and precise distribution of epiregulin and amphiregulin in the rat ovary using cycling adult rats as well as immature rats in which superovulation was induced by treatment with gonadotropins.

For the induction of superovulation, immature rats were treated with 30 IU PMSG for $48 \mathrm{~h}$, followed by 30 IU hCG. A Northern blot analysis revealed that PMSG treatment induced the expression of epiregulin mRNA after $24 \mathrm{~h}$, but this expression was decreased and became undetectable $48 \mathrm{~h}$ after the treatment. Further treatment with hCG rapidly induced the epiregulin gene expression again, and the maximal level was reached $4 \mathrm{~h}$ after the hCG treatment (Fig. 1A).

Using ovaries removed after $24 \mathrm{~h}$ of PMSG treatment or $4 \mathrm{~h}$ after hCG treatment (see Materials and methods) where strong expressions of the epiregulin gene were observed, in situ hybridization was performed. In both sets of ovaries (24 h after PMSG treatment or $4 \mathrm{~h}$ after hCG treatment), epiregulin mRNA was localized in the granulosa cells of large antral follicles (Fig. 1B).

To determine whether EGF-like growth factors other than epiregulin are also induced by gonadotropin treatment in the rat ovary, we examined the expression of various EGF family growth factor genes, and found that only amphiregulin mRNA was induced in ovaries stimulated with PMSG (data not shown).

The temporal expression pattern of amphiregulin mRNA in immature rats treated with PMSG followed by hCG was very similar to that of epiregulin (Fig. 2A). The only difference was that a small induction of amphiregulin mRNA was observed $6 \mathrm{~h}$ after PMSG treatment (Fig. 2A). We next examined amphiregulin mRNA localization in the ovary by in situ hybridization. In ovaries removed $24 \mathrm{~h}$ after PMSG treatment or $4 \mathrm{~h}$ after
hCG treatment, amphiregulin mRNA was also found to be localized in the granulosa cells of large antral follicles, as shown in Fig. 2B.

To characterize the expression patterns of these growth factors, they were compared with those of COX-2 and PR, both of which are known to be related to ovulation. As shown in Fig. 3A, COX-2 and PR transcripts were detected $24 \mathrm{~h}$ after PMSG treatment and decreased by $48 \mathrm{~h}$ after PMSG treatment. Further treatment of PMSG-primed rats with hCG rapidly induced these transcripts again with a peak at $4 \mathrm{~h}$. These temporal expression patterns were similar to those reported for epiregulin and amphiregulin. Furthermore, in situ hybridization analysis showed that all transcripts, COX-2, PR, epiregulin, and amphiregulin, were found in the same follicles (Fig. 3B). These results indicated that the spatio-temporal expression patterns of these growth factors were very similar to those of PR and COX-2.

We next examined whether these growth factors were also induced in cycling adult rats. RT-PCR was performed to detect epiregulin and amphiregulin mRNA in ovaries isolated from rats at various times during the 4-day estrous cycle. It is well known that a peak of the preovulatory LH surge occurs in the afternoon of proestrus. As shown in Fig. 4A, rat epiregulin and amphiregulin were induced at high levels at 1800 and $2000 \mathrm{~h}$ on proestrus. Transcripts of COX-2 and PR were also detected at high levels at 1800 and $2000 \mathrm{~h}$ on proestrus.

To determine the localization of these growth factors, we examined the distribution of these mRNAs in ovaries removed at $2000 \mathrm{~h}$ on proestrus. As shown in Fig. 4B, rat epiregulin and amphiregulin mRNAs were detected in preovulatory follicles, in which transcripts of COX-2 and PR were also induced.

\section{Discussion}

A number of studies have reported that EGF or TGF- $\alpha$ are associated with ovarian functions

Figure 3 Gene expression of epiregulin, amphiregulin, COX-2, and PR in immature rat ovaries. (A) Northern blot analysis of epiregulin, amphiregulin, COX-2, and PR mRNAs in the rat ovary. Ovaries were removed at the indicated times after treatment with PMSG or PMSG followed by hCG. (B) In situ hybiridization analysis of these mRNAs on adjacent ovarian sections. Ovaries were taken from 21-day-old immature rats treated with PMSG for $48 \mathrm{~h}$ and followed by $\mathrm{hCG}$ for $4 \mathrm{~h}$. Ovaries were dissected, sectioned, and hybridized with ${ }^{35} \mathrm{~S}$-labeled antisense epiregulin (a), amphiregulin (b), COX-2 (c), and PR (d) probes. A scale bar of $500 \mu \mathrm{m}$ is included. 
A

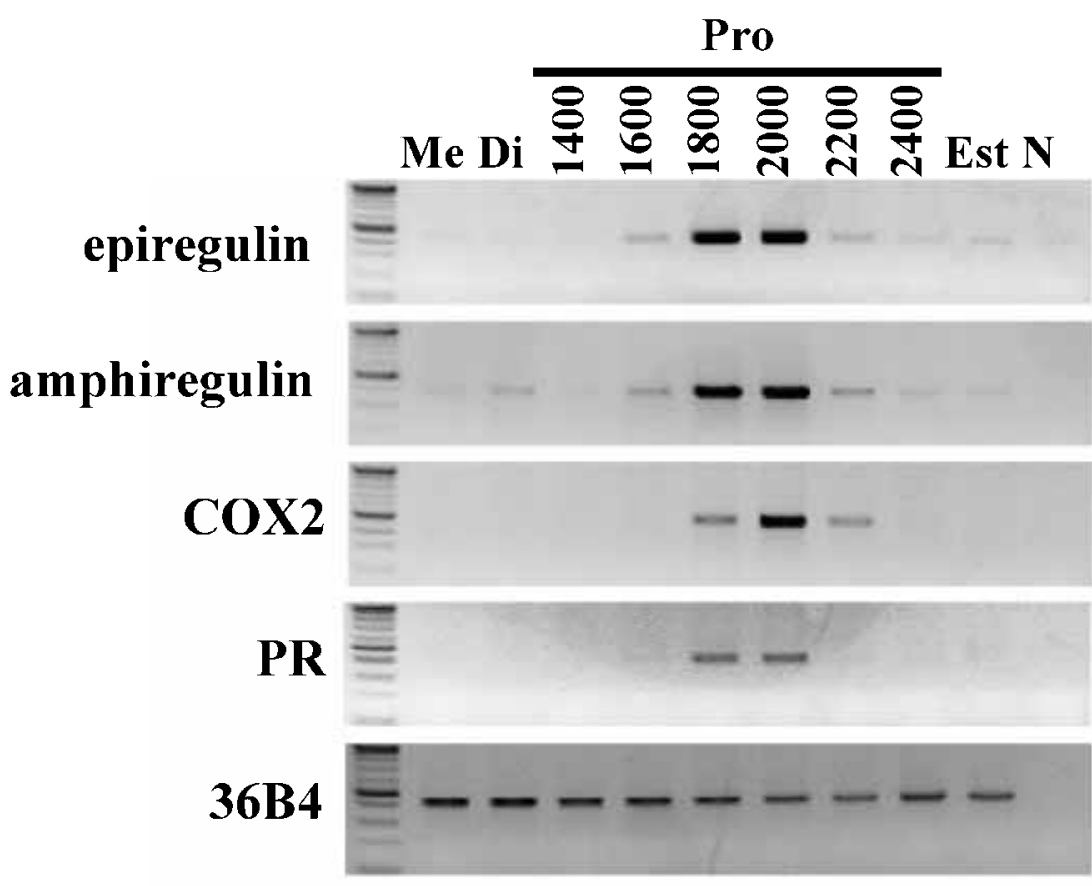

B

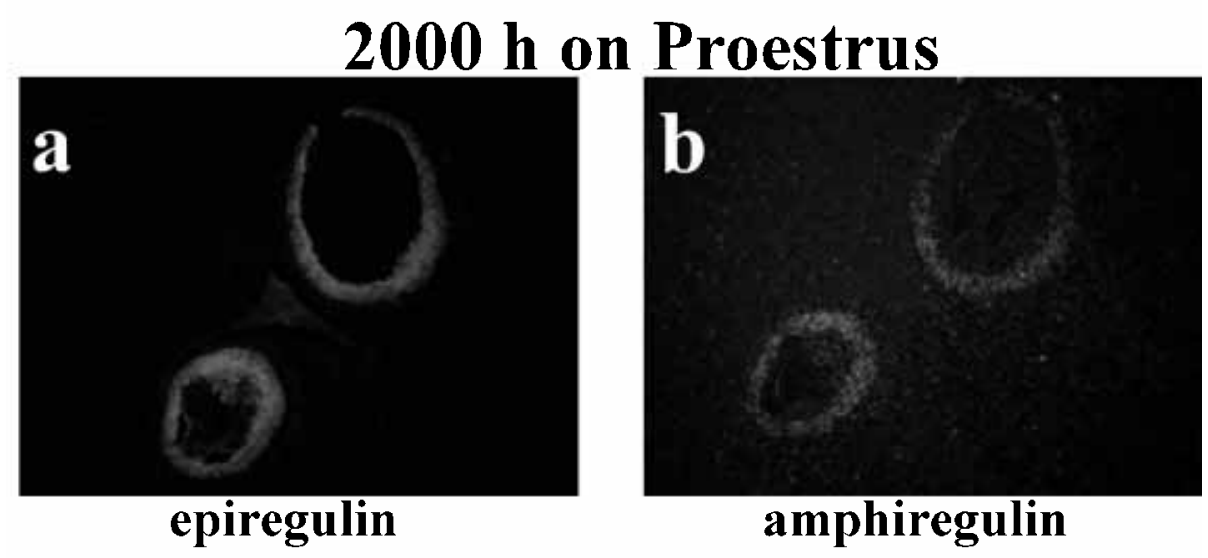

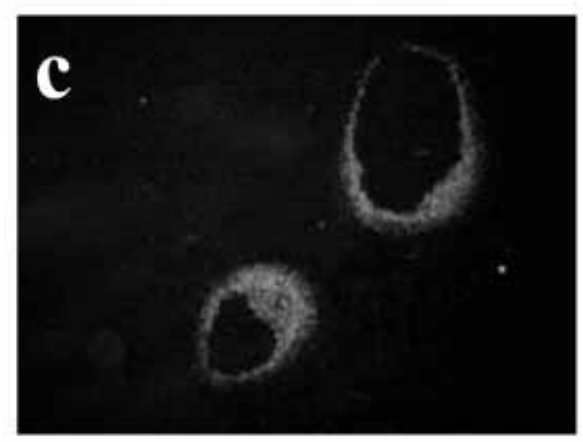

COX2

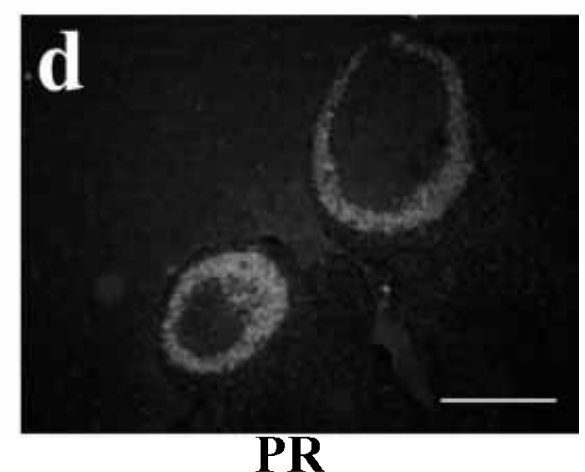


(Hsueh et al. 1981, Downs 1989, Roy \& Greenwald 1991, Das et al. 1992, Liang et al. 1994, Prochazka et al. 2000). However, most of these data were obtained from in vitro studies, and the physiological functions of these growth factors continue to remain unclear.

We have previously shown that the EGF family growth factor, epiregulin, is expressed in rat ovarian granulosa cells by induction with PMSG in vivo (Sekiguchi et al. 2002). Espey \& Richards (2002) also reported that epiregulin is one of 20 rat ovulation-specific genes identified by the molecular procedure known as differential display. In addition to epiregulin, we have demonstrated here that amphiregulin, another EGF-type growth factor, is also induced in the rat ovary as the result of gonadotropin treatment. A Northern blot analysis demonstrated that EGF, TGF- $\alpha$, heparin-bindingEGF (HB-EGF), betacellulin, and neuregulin transcripts were expressed weakly in the ovary but were not induced by either PMSG or hGG treatment (data not shown). These observations suggest that epiregulin and amphiregulin may participate in ovarian functions.

However, several reports have demonstrated that EGF family members are expressed in the ovary. Using an immunohistochemical procedure, EGFpositive cells were detected in the granulosa layer and the antrum of follicles (Fukumatsu et al. 1995). Kudlow et al. (1987) indicated that TGF- $\alpha$ is synthesized in the ovary, probably in the thecainterstitial compartments. It has also been reported that TGF- $\alpha$ is expressed in theca cells and is induced in rat follicle cultures by FSH treatment (Wang et al. 2002). Yeh et al. (1993), however, reported that TGF- $\alpha$ mRNA is expressed in cultured granulosa cells. The discrepancies between these and our observations need to be clarified in future experiments.

Our findings suggest that epiregulin and amphiregulin may be associated with phenomena induced by the preovulatory LH surge in the rat ovary. It is well known that cumulus expansion, a process necessary for the release of mature oocytes into the oviduct, is induced by an LH surge (Dekel \& Phillips 1979, Dekel et al. 1979, Robker et al. 2000) and that oocyte maturation, the re-initiation of meiosis that is signified by germinal vesicle breakdown, is also triggered by an LH surge (Channing et al. 1978). In vitro studies have shown that cumulus expansion (Channing et al. 1978, Eppig 1979, Salustri et al. 1990, Tirone et al. 1997) and oocyte maturation (Downs et al. 1988, Das et al. 1991, Kalous et al. 2003) could be induced by EGF. Because epiregulin and amphiregulin share common receptors with EGF (Prigent \& Lemoine 1992, Jones et al. 1999), it would be expected that these growth factors could also induce cumulus expansion and oocyte maturation. In addition, it has been reported that the expression of LH receptor mRNA was very low or undetectable in the cumulus cells of preovulatory follicles (Eppig et al. 1997). Therefore epiregulin and amphiregulin may serve as mediators of the LH surge which, in turn, serves as a signal for cumulus expansion and oocyte maturation. It is noteworthy that, in the gastric epithelial RGM1 cell line, epiregulin causes a significant increase in the expression of COX-2 mRNA and the corresponding protein (Sasaki et al. 1998). It can be easily concluded that epiregulin as well as amphiregulin may also be involved in the expression of COX-2 gene in the rat ovary. Further study will be needed to clarify the ovarian function of these growth factors further.

In summary, we report here that epiregulin and amphiregulin among EGF family members are induced in the rat ovary by gonadotropin treatment. These inductions appear to be associated with ovulation, because the temporal and spatial expression of these growth factor genes coincided with those of COX-2 and PR, both of which are known to be ovulation-related genes. We also found that epiregulin and amphiregulin transcripts were strongly induced in cyclic rats during the

Figure 4 Gene expression of epiregulin, amphiregulin, COX-2, and PR in cycling adult rats. Ovaries were removed at the indicated times (metestrus (Me), diestrus (Di), proestrus (Pro) and estrus (Est)) from adult female rats exhibiting at least two consecutive 4-day cycles. N, negative control. (A) Ovaries from various stages of cycling rats were used for RNA isolation and subsequent RT-PCR assays for epiregulin, amphiregulin, COX-2, and PR gene expression. (B) Ovaries were removed at $2000 \mathrm{~h}$ on proestrus, and were used for in situ hybridization to localize epiregulin, amphiregulin, COX-2, and PR mRNAs on adjacent sections. Ovaries were dissected, sectioned, and hybridized with ${ }^{35}$ S-labeled antisense epiregulin (a), amphiregulin (b), COX-2 (c), and PR (d) probes. A scale bar of $500 \mu \mathrm{m}$ is included. 
preovulatory LH surge, further supporting the roles of these growth factors in the ovulatory process.

\section{Acknowledgements}

We wish to thank Dr Takashi Higuchi and Dr Takuya Murata (Fukui University, Fukui, Japan) for advice about the determination of estrous cycles. We are also grateful to Dr Tamio Noguchi for providing the pGEM-T Easy-36B4, Ms Yoshiko Inoue for secretarial assistance, and members of the Miyamoto laboratory for helpful discussion and technical assistance. This work was supported in part by a grant from the Smoking Research Foundation and by 21 st Century Centre of Excellence Program (Medical Science).

\section{References}

Burns KH, Owens GE, Ogbonna SG, Nilson JH \& Matzuk MM 2003 Expression profiling analyses of gonadotropin responses and tumor development in the absence of inhibins. Endocrinology 144 4492-4507.

Channing CP, Hillensjo T \& Schaerf FW 1978 Hormonal control of oocyte meiosis, ovulation and luteinization in mammals. Clinics in Endocrinology and Metabolism 7 601-624.

Chomczynski P \& Sacchi N 1987 Single-step method of RNA isolation by acid guanidinium thiocyanate-phenol-chloroform extraction. Analytical Biochemistry 162 156-159.

Das K, Stout LE, Hensleigh HC, Tagatz GE, Phipps WR \& Leung BS 1991 Direct positive effect of epidermal growth factor on the cytoplasmic maturation of mouse and human oocytes. Fertility and Sterility 55 1000-1004.

Das K, Phipps WR, Hensleigh HC \& Tagatz GE 1992 Epidermal growth factor in human follicular fluid stimulates mouse oocyte maturation in vitro. Fertility and Sterility 57 895-901.

Dekel N \& Phillips DM 1979 Maturation of the rat cumulus oophorus. A scanning electron microscopic study. Biology of Reproduction 21 9-18.

Dekel N, Hillensjo T \& Kraicer PF 1979 Maturational effects of gonadotropins on the cumulus-oocyte complex of the rat. Biology of Reproduction 20 191-197.

Downs SM 1989 Specificity of epidermal growth factor action on maturation of the murine oocyte and cumulus oophorus in vitro. Biology of Reproduction 41 371-379.

Downs SM, Daniel SA \& Eppig.JJ 1988 Induction of maturation in cumulus cell-enclosed mouse oocytes by follicle-stimulating hormone and epidermal growth factor: evidence for a positive stimulus of somatic cell origin. Fournal of Experimental Zoology 245 86-96.

Eppig JJ 1979 Gonadotropin stimulation of the expansion of cumulus oophori isolated from mice: general conditions for expansion in vitro. Fournal of Experimental Zoology 208 111-120.

Eppig JJ, Wigglesworth K, Pendola F \& Hirao Y 1997 Murine oocytes suppress expression of luteinizing hormone receptor messenger ribonucleic acid by granulosa cells. Biology of Reproduction 56 976-984.

Espey LL \& Richards JS 2002 Temporal and spatial patterns of ovarian gene transcription following an ovulatory dose of gonadotropin in the rat. Biology of Reproduction 67 1662-1670.
Fukumatsu Y, Katabuchi H \& Okamura H 1995

Immunohistochemical localization of epidermal growth factor and its effect on granulosa cell proliferation in rat ovary. Endocrine Journal 42 467-473.

Hsueh AJ, Welsh TH \& Jones PB 1981 Inhibition of ovarian and testicular steroidogenesis by epidermal growth factor. Endocrinology 108 2002-2004.

Jones JT, Akita RW \& Sliwkowski MX 1999 Binding specificities and affinities of EGF domains for ErbB receptors. FEBS Letters 447 227-231.

Kalous J, Kubelka M \& Motlik J 2003 The effect of PD98059 on MAPK regulation in cumulus-enclosed and cumulus-free mouse oocytes. Zygote 11 61-68.

Kameda T, Mizutani T, Minegishi T, Ibuki Y \& Miyamoto K 1999 Regulation of cAMP responsive element binding modulator isoforms in cultured rat ovarian granulosa cells. Biochimica et Biophysica Acta 1445 31-38.

Kimura H, Fischer WH \& Schubert D 1990 Structure, expression and function of a Schwannoma-derived growth factor. Nature 348 257-260.

Knauthe R, Diel P, Hegele-Hartung C, Engelhaupt A \& Fritzemeier KH 1996 Sexual dimorphism of steroid hormone receptor messenger ribonucleic acid expression and hormonal regulation in rat vascular tissue. Endocrinology 137 3220-3227.

Kudlow JE, Kobrin MS, Purchio AF, Twardzik DR, Hernandez ER, Asa SL \& Adashi EY 1987 Ovarian transforming growth factor-alpha gene expression: immunohistochemical localization to the theca-interstitial cells. Endocrinology 121 1577-1579.

Lee SB, Huang K, Palmer R, Truong VB, Herzlinger D, Kolquist KA, Wong J, Paulding C, Yoon SK, Gerald W et al. 1999 The Wilms tumor suppressor WT1 encodes a transcriptional activator of amphiregulin. Cell 98 663-673.

Leung PC \& Steele GL 1992 Intracellular signaling in the gonads. Endocrine Reviewes 13 476-498.

Liang SG, Yano T, Tsutsumi O \& Taketani Y 1994 Modulatory role of epidermal growth factor in follicle-stimulating hormone-induced DNA synthesis in cultured rat granulosa cells. Endocrine Fournal 41 319-323.

Prigent SA \& Lemoine NR 1992 The type 1 (EGFR-related) family of growth factor receptors and their ligands. Progress in Growth Factor Research 4 1-24.

Prochazka R, Srsen V, Nagyova E, Miyano T \& Flechon JE 2000 Developmental regulation of effect of epidermal growth factor on porcine oocyte-cumulus cell complexes: nuclear maturation, expansion, and F-actin remodeling. Molecular Reproduction and Development 56 63-73.

Richards JS 1994 Hormonal control of gene expression in the ovary. Endocrine Reviewes 15 725-751.

Robert C, Gagne D, Bousquet D, Barnes FL \& Sirard MA 2001 Differential display and suppressive subtractive hybridization used to identify granulosa cell messenger RNA associated with bovine oocyte developmental competence. Biology of Reproduction $\mathbf{6 4}$ $1812-1820$.

Robker RL, Russell DL, Yoshioka S, Sharma SC, Lydon JP, O'Malley BW, Espey LL \& Richards JS 2000 Ovulation: a multi-gene, multi-step process. Steroids 65 559-570.

Roy SK \& Greenwald GS 1991 Mediation of follicle-stimulating hormone action on follicular deoxyribonucleic acid synthesis by epidermal growth factor. Endocrinology 129 1903-1908.

Salustri A, Ulisse S, Yanagishita M \& Hascall VC 1990 Hyaluronic acid synthesis by mural granulosa cells and cumulus cells in vitro is selectively stimulated by a factor produced by oocytes and by transforming growth factor-beta. Fournal of Biological Chemistry 265 19517-19523.

Sasaki E, Pai R, Halter F, Komurasaki T, Arakawa T, Kobayashi K, Kuroki T \& Tarnawski AS 1998 Induction of cyclooxygenase-2 in a rat gastric epithelial cell line by epiregulin and basic 
fibroblast growth factor. Fournal of Clinical Gastroenterology 27 21-27.

Schuger L, Johnson GR, Gilbride K, Plowman GD \& Mandel R 1996 Amphiregulin in lung branching morphogenesis: interaction with heparan sulfate proteoglycan modulates cell proliferation. Development 122 1759-1767.

Sekiguchi T, Mizutani T, Yamada K, Yazawa T, Kawata H, Yoshino M, Kajitani T, Kameda T, Minegishi T \& Miyamoto K 2002 Transcriptional regulation of the epiregulin gene in the rat ovary. Endocrinology $1434718-4729$.

Shoyab M, McDonald VL, Bradley JG \& Todaro GJ 1988 Amphiregulin: a bifunctional growth-modulating glycoprotein produced by the phorbol 12-myristate 13-acetate-treated human breast adenocarcinoma cell line MCF-7. PNAS 85 6528-6532.

Tirone E, D'Alessandris C, Hascall VC, Siracusa G \& Salustri A 1997 Hyaluronan synthesis by mouse cumulus cells is regulated by interactions between follicle-stimulating hormone (or epidermal growth factor) and a soluble oocyte factor (or transforming growth factor beta1). Fournal of Biological Chemistry 272 4787-4794.

Toyoda H, Komurasaki T, Uchida D, Takayama Y, Isobe T, Okuyama T \& Hanada K 1995a Epiregulin. A novel epidermal growth factor with mitogenic activity for rat primary hepatocytes. Journal of Biological Chemistry 270 7495-7500.

Toyoda H, Komurasaki T, Ikeda Y, Yoshimoto M \& Morimoto S $1995 b$ Molecular cloning of mouse epiregulin, a novel epidermal growth factor-related protein, expressed in the early stage of development. FEBS Letters 27 403-407.

Toyoda H, Komurasaki T, Uchida D \& Morimoto S 1997 Distribution of mRNA for human epiregulin, a differentially expressed member of the epidermal growth factor family. Biochemical fournal 15 69-75.

Wang Y, Asselin E \& Tsang BK 2002 Involvement of transforming growth factor alpha in the regulation of rat ovarian X-linked inhibitor of apoptosis protein expression and follicular growth by follicle-stimulating hormone. Biology of Reproduction 66 1672-1680.

Yamada K, Kawata H, Shou Z, Mizutani T, Nouguchi T \& Miyamoto K 2003 Insulin induces the expression of the SHARP-2/Stra13/DEC1 gene via phosphoinositide 3-kinase pathway. Fournal of Biological Chemistry 278 30719-30728.

Yeh J, Lee GY \& Anderson E 1993 Presence of transforming growth factor-alpha messenger ribonucleic acid (mRNA) and absence of epidermal growth factor mRNA in rat ovarian granulosa cells, and the effects of these factors on steroidogenesis in vitro. Biology of Reproduction 48 1071-1081.

Received 12 November 2003

Accepted 26 April 2004

Made available online as an Accepted Preprint 6 May 2004

www.endocrinology.org 